\title{
Pequi kernel oil extraction by hydraulic pressing and its characterization
}

\author{
Janice Ribeiro Lima ${ }^{1}$, Arthur Claudio Rodrigues de Souza ${ }^{2}$, \\ Hilton César Rodrigues Magalhães ${ }^{3}$, Cláudia Oliveira Pinto ${ }^{4}$
}

\begin{abstract}
The seed by-products of pequi pulp processing have a kernel in its core which is not used due to the difficulty of its extraction from the spinous endocarp. However, this kernel has high quality oil which can be used for human consumption. Thus, the kernel and the oil composition as well as the conditions to obtain the kernel oil by hydraulic pressing were evaluated in this study. The kernel showed high lipid content $(55.76 \%)$, therefore being a good source for obtaining oil. The oil extraction by hydraulic pressing presented a higher yield at 5.5 tons to 6.0 tons of force and $9 \%$ to $10 \%$ moisture. Oil recovery was $75 \%$. The pequi kernel oil showed low acid $(0.17 \mathrm{mg} \mathrm{KOH} / \mathrm{g})$ and peroxide $\left(1.22 \mathrm{mEq} \mathrm{O}_{2} / \mathrm{kg}\right.$ ) values. The kernel oil also presented high levels of oleic acid (42.47\%). The results indicate that the kernel oil extraction is an alternative form for using seeds to increase the producer/processor income and to decrease residue volumes in the pequi processing industry.

Index terms: Caryocar coriaceum, Lipid, Oil recovery, Oil yield. \section{hidráulica e sua caracterização}

Extração de óleo de amêndoa do Pequi por prensagem
\end{abstract}

Corresponding author: janice.lima@embrapa.br

Received: May 19, 2020 Accepted: June 29, 2020

Copyright: All the contents of this journal, except where otherwise noted, is licensed under a Creative Commons Attribution License.
Resumo- Os caroços, subprodutos do processamento da polpa de pequi, têm em seu núcleo uma amêndoa que não é utilizada devido à dificuldade de sua extração a partir do endocarpo espinhoso. No entanto, essa amêndoa possui óleo de alta qualidade que pode ser usado para consumo humano. Neste trabalho, avaliaram-se a composição da amêndoa e do óleo, bem como as condições de obtenção do óleo da amêndoa por prensagem hidráulica. A amêndoa apresentou alto teor lipídico (55,76\%), sendo boa fonte de obtenção de óleo. A extração de óleo por prensagem hidráulica apresentou maior rendimento nas faixas de 5,5 ton a 6,0 ton de força e $9 \%$ a $10 \%$ de umidade. A recuperação de óleo foi de $75 \%$. O óleo de amêndoa de pequi apresentou baixos valores de índice de acidez $(0,17 \mathrm{mg}$ $\mathrm{KOH} / \mathrm{g})$ e peróxidos $(1,22 \mathrm{mEq} \mathrm{O} 2 / \mathrm{kg})$. Além disso, o óleo de amêndoa apresentou altos níveis de ácido oleico $(42,47 \%)$. Esses resultados indicam que a extração de óleo de amêndoa é uma forma alternativa de utilização de caroços para aumentar a renda do produtor / processador e para diminuir o volume de resíduos no processamento de pequi.

Termos para indexação: Caryocar coriaceum, lipídeo, recuperação de óleo, rendimento em óleo.

\footnotetext{
${ }^{1}$ Dr. in Food Technology, Researcher, Embrapa Food Agroindustry, Rio de Janeiro-RJ, Brazil. Email: janice.lima@embrapa.br (ORCID 0000-0003-1001-2067)

${ }^{2}$ Msc. in Chemical Engineering, Analyst, Embrapa Tropical Agroindustry, Fortaleza-CE, Brazil. Email: arthur.souza@embrapa.br (ORCID 0000-0003-2786-555X)

${ }^{3}$ MSc. in Food Science, Analyst, Embrapa Tropical Agroindustry, Fortaleza-CE, Brazil. Email: hilton.magalhaes@embrapa.br (ORCID 0000-0002-0531-2527)

${ }^{4}$ Food Engineer, Analyst, Embrapa Dairy Cattle, Juiz de Fora-MG, Brazil. Email: claudia.pinto@embrapa.br ${ }^{\text {(ORCID 0000-0003-0079- }}$ 0172)
} 


\section{Introduction}

The pequi tree belongs to the Caryocaraceae family and the $C$. coriaceum species mainly occurs in the Mid-North of Brazil (Maranhão and Piauí States) and in the States of Ceará, Bahia, Pernambuco and Goiás (LORENZI, 1992; RAMOS; SOUZA, 2011). However, the C. coriaceum species has not received due attention from researchers. Few studies are available in the literature involving the production and chemicalnutritional characterization of fruits of this species (SILVA; MEDEIROS FILHO, 2006; OLIVEIRA et al., 2010a, OLIVEIRA et al. 2010b, RAMOS; SOUZA, 2011).

The edible pequi kernel is considered a by-product mainly due to the difficulty in extracting it from the spiny endocarp. The kernel can be used in oil extraction, as an ingredient in flour and sweets, or as a snack in salty or sweet form (DAMIANI et al., 2013; ALVES et al., 2014).

Ramos and Souza (2011) reported that pequi fruit seeds (Caryocar coriaceum) from the Maranhão and Piauí regions have an average weight of $25.9 \mathrm{~g}$, and its kernels are $1.8 \mathrm{~g}$. Araújo et al. (2018) reported proximate composition of pequi kernels (Caryocar coriaceum) as $50.0 \%$ lipids, $5.8 \%$ ash, $33.3 \%$ protein, $5.0 \%$ fiber and $5.7 \%$ carbohydrates.

Lima et al. (2007) found four major components in pequi kernels (Caryocar brasiliense): lipids (51.5\%), proteins $(25.3 \%)$, carbohydrates $(8.3 \%)$ and dietary fiber $(2.2 \%)$, with a low moisture content $(8.7 \%)$ and a high mineral content represented by ashes $(4.0 \%)$. According to these authors, the main fatty acids of the pequi kernel are palmitic $(43.76 \%)$ and oleic $(43.59 \%)$.

Aguilar et al. (2011) studied the effect of a diet supplemented with pequi (Caryocar brasiliense) on blood lipid and glycemic levels and liver histology in mice. The authors observed that total cholesterol serum and HDLcholesterol were significantly higher in mice fed diets containing pequi kernels at $33 \%$. However, there was no change in blood levels of triglycerides, atherogenic fraction and glucose. Torres et al. (2016) reported that pequi kernel oil (Caryocar brasiliense) extracted by cold pressing attenuates liver damage induced in rats by carbon tetrachloride due to its antioxidant and anti-inflammatory properties. Oliveira et al. (2010b) also reported the topical anti-inflammatory action of pequi kernel oil (Caryocar coriaceum) and the accelerated recovery of skin lesions.

Therefore, the objective of this work was to evaluate the extraction of pequi (Caryocar coriaceum) kernel oil by hydraulic pressing and to characterize its contents. The oil obtained from the pequi kernel is an alternative use for the by-product generated in the pequi pulp industrial process.

\section{Material and Methods}

\section{Pequi kernel}

Pequi seeds (Caryocar coriaceum) were obtained in Chapada do Araripe, Ceará, Brazil as a residue from pulp extraction. They were washed in running water and sanitized in chlorinated solution $(200 \mathrm{mg} / \mathrm{L})$ for 15 min, followed by oven drying at $60{ }^{\circ} \mathrm{C}$ for $24 \mathrm{~h}$. Kernels were obtained by cutting the seeds in halves with a guillotine and manually removing the skin. Kernels were characterized for moisture, ashes, total lipids, proteins ( $\mathrm{N}$ $x$ 6.25) and total carbohydrates (by difference) with the analysis determined in triplicate (INSTITUTO ADOLFO LUTZ, 2008).

\section{Extraction of kernel oil by hydraulic pressing}

As the moisture is one of the experimental design variable the pequi kernels were ground (Robot Coupe R502V.V, Vincennes, France) and dried at $110^{\circ} \mathrm{C}$ for two hours in order to allow subsequent moisture adjustment. Moisture was determined (INSTITUTO ADOLFO LUTZ, $2008)$ in the ground kernels and water $(\mathrm{m} / \mathrm{m})$ was added to adjust the moisture according to the values of the experimental design detailed below. The samples with the added water were kept for $24 \mathrm{~h}$ in sealed multilayer bags for moisture homogenization. For the pressing tests, $35 \mathrm{~g}$ of samples were packed in TNT60 bags that remained in an oven for $15 \mathrm{~min}$ at $40^{\circ} \mathrm{C}$ for temperature stabilization. The bags were placed in a stainless steel cylinder $\left(18 \mathrm{~cm}^{2}\right.$ of base area) and pressed by a piston until the test force, remaining at this force for 3 min (hydraulic press Skay, Apiguana, Fortaleza, Brazil). The yield was calculated as the ratio between the amount of oil obtained and the amount of kernels, expressed by percentage $(\%, \mathrm{~m} / \mathrm{m})$.

A central composite design was implemented for the tests with two independent variables (moisture and force) and three repetitions in the central point $\left(2^{2}\right.$ $+2(2)+3 \mathrm{CP}$ ), totaling 11 trials (Table 1$)$. The yield $(\%, \mathrm{~m} / \mathrm{m})$ was used as the dependent variable (answer). Statistical analyses of the data were performed by ANOVA (analysis of variance) using Protimiza Software (2020) to determine the variables which had significant effects on the dependent variables at $\mathrm{p}<0.10$. 
Table 1. Values and levels used in the central composite design to evaluate pequi (Caryocar coriaceum) kernel oil extraction by hydraulic pressing.

\begin{tabular}{cccccc}
\hline \multirow{2}{*}{ Variables } & \multicolumn{5}{c}{ Levels } \\
\cline { 2 - 6 } & -1.41 & -1 & 0 & +1 & +1.41 \\
\hline Moisture (\%) & 2.0 & 3.2 & 6.0 & 8.8 & 10.0 \\
Force (ton) & 2.0 & 2.6 & 4.0 & 5.4 & 6.0 \\
\hline
\end{tabular}

\section{Pequi kernel oil analysis}

Oil obtained in the best conditions determined in the experiment described previously was analyzed for acid and peroxide values (AOCS, 1988). Calculated iodine value was determined using the fatty acid composition of the oil and factors approved by AOCS (1988). The saponification value was estimated from the fatty acid composition by recalculating the average molecular weight of the fatty acids, considering that three moles of $\mathrm{KOH}$ are needed to saponify one mole of triacylglycerol. Fatty acid composition was determined through the methyl esters (FAMEs) obtained according to Hartmann and Lago (1973). FAMEs were determined by gas chromatography using a Shimadzu 2010 Plus device, equipped with a flame ionization detector (FID), a SP2560 column (100\% bis-cyanopropyl polysiloxane; Supelco Bellefonte, USA) with dimensions of $100 \mathrm{~m} \times 0.25 \mathrm{~mm}$ id $\times 0.20 \mu \mathrm{m}$ df. The carrier gas (hydrogen) flow rate was $1.5 \mathrm{~mL} / \mathrm{min}$. The temperatures of the injection port and detector were $220^{\circ} \mathrm{C}$ and $230{ }^{\circ} \mathrm{C}$, respectively. The $\mathrm{GC}$ oven was programmed as follows: column initial temperature of $80^{\circ} \mathrm{C}$, increasing at the rate of $11.0{ }^{\circ} \mathrm{C} / \mathrm{min}$ to $180{ }^{\circ} \mathrm{C}$, then at $5.0{ }^{\circ} \mathrm{C} / \mathrm{min}$ to $220^{\circ} \mathrm{C}$ and held for 9 minutes. FAMEs were identified by comparing the retention time of samples and the appropriate fatty acid methyl ester standards purchased from Supelco (Bellefonte, USA). Each fatty acid was expressed in percentages of relative area, obtained by area normalization (fatty acid peak area relative to the total area of the chromatogram).

\section{Results and Discussion}

\section{kernel \\ Physico-chemical characterization of pequi}

The proximate composition of the pequi kernel is shown in Table 2. For pequi kernels from Caryocar coriaceum Ramos and Souza (2011) reported 2.4\% ash, $48.5 \%$ lipids, $27.1 \%$ proteins and $21.9 \%$ of carbohydrates (on a dry basis), while Araújo et al. (2018) reported 5.8\% ash, $50.0 \%$ lipids, $33.3 \%$ protein, $5.0 \%$ fiber, and $5.7 \%$ carbohydrates. Despite the variations between the results, it can be observed that the kernel is characterized by its high lipid content, therefore being a potential raw material for obtaining edible oil.

Table 2. Proximate composition of dried pequi kernel (Caryocar coriaceum) $(n=3)$.

\begin{tabular}{cc}
\hline Determination & $\%( \pm \mathrm{sd})$ \\
\hline Moisture & $0.65( \pm 0.05)$ \\
Ashes & $0.28( \pm 0.03)$ \\
Proteins & $29.24( \pm 0.74)$ \\
Lipids & $55.76( \pm 0.65)$ \\
Carbohydrates & $14.07( \pm 0.80)$ \\
\hline
\end{tabular}

\section{Pequi kernel oil extraction by hydraulic pressing}

The values obtained in the central composite design in which the influence of force and moisture on the kernel oil yield was studied are shown in Table 3. The linear and quadratic regression coefficients for force and linear regression coefficients for moisture were significant $(p<0.10)$ (Table 4). The analysis of variance showed that the variation percentage explained by the model was 93.5\% (Table 5). The results showed that both force and moisture influenced the oil extraction yield, and observing the contour plot (Figure 1) enables us to conclude that the optimal range for extraction is 5.5 ton to 6.0 ton of force and $9 \%$ to $10 \%$ moisture. The values were at the end of the scales, however preliminary tests showed that greater forces broke the TNT bag, thereby invalidating the process and higher moisture produces a paste which cannot be pressed. The yield was approximately $42 \%$ in relation to the pequi kernel weight, which was $75 \%$ of the total kernel oil content. The results were higher than those found by Lima et al. (2018) who reported $29 \%$ to $32 \%$ yield in the extraction of cashew kernel oil, and Navarro and Rodrigues (2016) who reported 35\% to $40 \%$ yield for macadamia oil, both by pressing. 


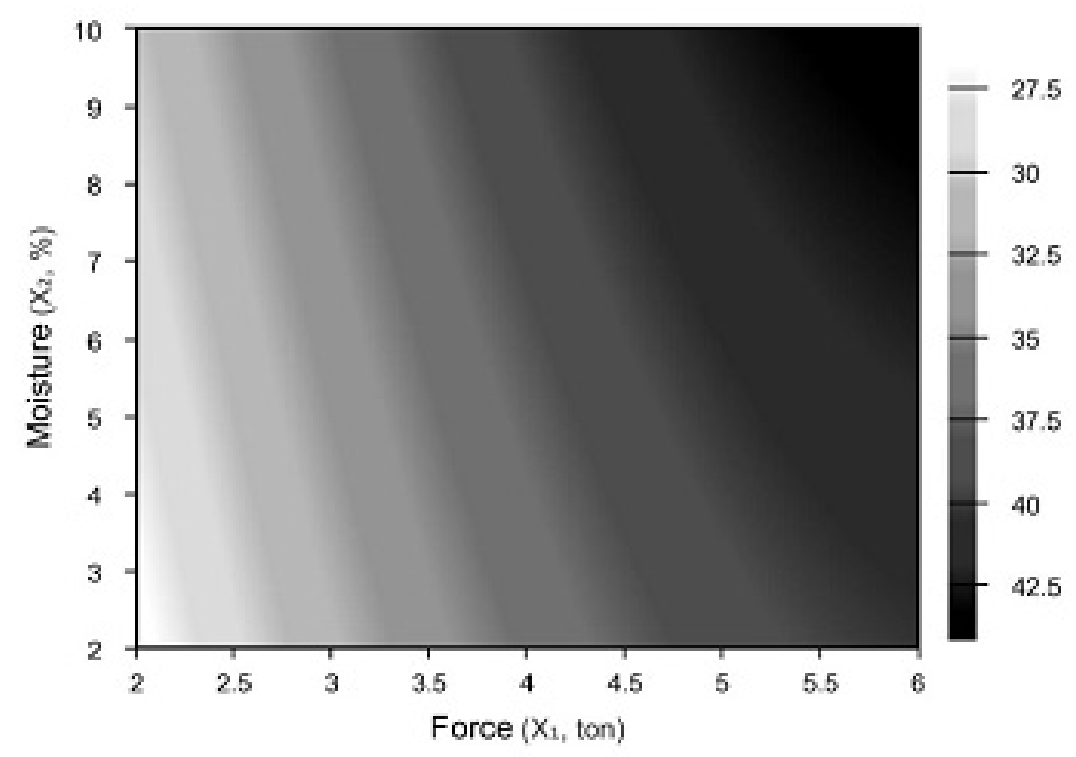

Figure 1. Contour plot for yield $(\%, \mathrm{~m} / \mathrm{m})$ in pequi (Caryocar coriaceum) kernel oil extraction by hydraulic pressing.

Table 3. Central composite design matrix and experimental results for pequi (Caryocar coriaceum) kernel oil extraction by hydraulic pressing.

\begin{tabular}{|c|c|c|c|c|c|}
\hline \multirow{2}{*}{ Essay } & \multirow{2}{*}{\multicolumn{2}{|c|}{ Coded levels }} & \multicolumn{2}{|c|}{ Decoded levels } & \multirow{2}{*}{$\begin{array}{c}\text { Yield } \\
(\%, \mathrm{~m} / \mathrm{m})\end{array}$} \\
\hline & & & Force (ton) & Moisture (\%) & \\
\hline 1 & -1 & -1 & 2.6 & 3.2 & 29.32 \\
\hline 2 & 1 & -1 & 5.4 & 3.2 & 41.24 \\
\hline 3 & -1 & 1 & 2.6 & 8.8 & 31.52 \\
\hline 4 & 1 & 1 & 5.4 & 8.8 & 41.55 \\
\hline 5 & -1.41 & 0 & 2.0 & 6.0 & 29.66 \\
\hline 6 & 1.41 & 0 & 6.0 & 6.0 & 42.03 \\
\hline 7 & 0 & -1.41 & 4.0 & 2.0 & 34.84 \\
\hline 8 & 0 & 1.41 & 4.0 & 10.0 & 40.82 \\
\hline 9 & 0 & 0 & 4.0 & 6.0 & 36.33 \\
\hline 10 & 0 & 0 & 4.0 & 6.0 & 38.83 \\
\hline 11 & 0 & 0 & 4.0 & 6.0 & 39.19 \\
\hline
\end{tabular}

Table 4. Central composite design regression coefficients for yield $(\%, \mathrm{~m} / \mathrm{m})$ in pequi (Caryocar coriaceum) kernel oil extraction by hydraulic pressing.

\begin{tabular}{ccccc}
\hline & Regression coefficients & Standart error & calculated $\mathrm{t}$ & $p$-value \\
\hline Mean & 37.76 & 0.62 & 61.05 & 0.0000 \\
$\mathrm{x}_{1}$ & 4.93 & 0.52 & 9.47 & 0.0000 \\
$\mathrm{x}_{1}{ }^{2}$ & -1.26 & 0.59 & -2.12 & 0.0713 \\
$\mathrm{x}_{2}$ & 1.37 & 0.52 & 2.63 & 0.0337 \\
\hline
\end{tabular}

$\mathrm{x}_{1}=$ Force (ton); $\mathrm{x}_{2}=$ Moisture $(\%)$.

Table 5. ANOVA for yield $(\%, \mathrm{~m} / \mathrm{m})$ in pequi (Caryocar coriaceum) kernel oil extraction by hydraulic pressing $\left(\mathrm{R}^{2}=93.5 \%\right)$.

\begin{tabular}{cccccc}
\hline Variation source & Sum of squares & Degrees of freedom & Mean square & $\mathrm{F}_{\text {calc }}$ & $p$-valor \\
\hline Regression & 219.3 & 3 & 73.1 & 33.7 & 0.00016 \\
Residuals & 15.2 & 7 & 2.2 & & \\
Lack of fit & 10.3 & 5 & 2.1 & 0.9 & 0.61838 \\
Pure error & 4.9 & 2 & 2.4 & & \\
Total & 234.5 & 10 & & & \\
\hline
\end{tabular}




\section{Characteristics of the pequi kernel oil}

The acid value $(0.17 \mathrm{mg} \mathrm{KOH} / \mathrm{g})$ observed was smaller than the maximum limit allowed for cold-pressed and unrefined oils in Brazilian legislation and in Codex Alimentarius (4.0 mg KOH/g) (ANVISA, 2005; CODEX ALIMENTARIUS, 2003). Likewise, the peroxide value observed $(1.22 \mathrm{mEq} \mathrm{O} / 2 \mathrm{~kg})$ was smaller than the limit in those legislations $\left(15 \mathrm{mEq} \mathrm{O}_{2} / \mathrm{kg}\right)$. Both results reflected good quality oil (Table 6). Calculated iodine value was lower than the values ranging from 74.2 to $113.8 \mathrm{~g} \mathrm{I}_{2} / 100 \mathrm{~g}$ oil reported by Moodley et al. (2007) for other kernels oils (macadamia, pecan, brazil, walnut and almond), which reflects the high saturated fatty acids content of the pequi kernel oil. The saponification value was also out of the range of 182.5 to $193.7 \mathrm{mg} \mathrm{KOH} / \mathrm{g}$ oil reported by those authors for common kernels oils.

Table 6. Chemical characteristics and fatty acid composition of pequi (Caryocar coriaceum) kernel oil extracted by hydraulic pressing.

\begin{tabular}{cc}
\hline Determination & mean $\pm \mathrm{sd}$ \\
\hline Acid value $(\mathrm{mg} \mathrm{KOH} / \mathrm{g})$ & $0.17 \pm 0.02$ \\
Peroxide value $(\mathrm{mEq} / \mathrm{kg})$ & $1.22 \pm 0.02$ \\
Iodine value* $\left(\mathrm{g} \mathrm{I}_{2} / 100 \mathrm{~g}\right)$ & 54.13 \\
Saponification value* $(\mathrm{mg} \mathrm{KOH} / \mathrm{g})$ & 209.65 \\
\hline Fatty acid $(\%)$ & \\
\hline Miristic $(\mathrm{C} 14: 0)$ & $0.22 \pm 0.03$ \\
Palmitic $(\mathrm{C} 16: 0)$ & $39.49 \pm 3.03$ \\
Estearic $(\mathrm{C} 18: 0)$ & $1.63 \pm 0.13$ \\
Oleic $(\mathrm{C} 18: 1 \mathrm{cis})$ & $42.47 \pm 2.11$ \\
Linoleic $(\mathrm{C} 18: 2$ cis, cis) & $10.17 \pm 0.55$ \\
Not identified & 6.02 \\
$\sum$ Saturated & 41.34 \\
$\sum$ Unsaturated & 52.63 \\
\hline calculated from the fatty acids average percentages
\end{tabular}

The major fatty acids in pequi kernel oil were oleic $(42.47 \%)$ and palmitic (39.49\%), followed by linoleic acid $(10.17 \%)$ (Table 6), which agrees with the results reported by Lima et al. (2007) and Torres et al. (2016). In addition to the benefits of consuming oils with high monounsaturated fatty acids content to prevent cardiovascular diseases (ALVES et al., 2016), some authors have reported antiinflammatory action related to the consumption of pequi kernel oil (TORRES et al., 2016), as well as its topical use (OLIVEIRA et al., 2010b).

\section{Conclusions}

Pequi kernel have $55.76 \%$ of lipids, therefore being a good source for edible oil. The optimum ranges for oil extraction by hydraulic pressing are 5.5 ton to 6.0 ton of force and $9 \%$ to $10 \%$ moisture, with oil yield of approximately $42 \%$ in relation to the pequi kernel weight, representing $75 \%$ of oil recovery. In addition, pequi kernel oil is an excellent source of monounsaturated fatty acids for human consumption. Thus, the use of this by-product from pequi pulp production can became a new income source for the producing regions.

\section{References}

AGUILAR, E.C.; QUEIROZ, M.G.M.N.; OLIVEIRA, D.A.; OLIVEIRA, N.J.F. Serum lipid profile and hepatic evaluation in mice fed diet containing pequi nut or pulp (Caryocar brasiliense Camb.). Ciência e Tecnologia de Alimentos, Campinas, v.31, n.4, p.879-883, 2011.

ALVES, A.M.; FERNANDES, D.C.; BORGES, J.F.; SOUSA, A.G.O.; NAVES, M.M.V. Oilseeds native to the Cerrado have fatty acid profile beneficial for cardiovascular health. Revista de Nutrição, Araraquara, v.29, n.6, p.859-866, 2016.

ALVES, A.M.; FERNANDES, D.C.; SOUSA, A.G.O.; NAVES, R.V.; NAVES, M.M.V. Características físicas e nutricionais de pequis oriundos dos estados de Tocantins, Goiás e Minas Gerais. Brazilian Journal of Food Technology, Campinas, v.17, n.3, p.198-203, 2014. 
ANVISA - Agencia Nacional de Vigilância Sanitária. Resolução RDC n 270 de 22 de setembro de 2005. Regulamento técnico para óleos vegetais, gorduras vegetais e creme vegetal. Brasília, 2005 Disponível em: http://portal.anvisa.gov.br/documents/10181/2718376/ RDC 270_2005 .pdf/8f80bf4d-a38a-4699-9f8f582186b3797d. Acesso em: 14 maio 2020.

AOCS - American Oil Chemists Society. Official methods and reccomended practices of the American Oil Chemists Society. $5^{\text {th }}$ ed. Champaign, 2003.

CODEX ALIMENTARIUS (FAO/WHO). Codex standard for named negetable oils, Codex Stan 210 (Amended 2003). Roma, 2003. Disponível em: https:// mvo.nl/media/voedselveiligheid/codex_standard_named vegetable_oils.pdf Acesso em: 19 jun. 2020.

ARAÚJO, A.C.M.A.; MENEZES, E.G.T.; TERRA, A.W.C.; DIAS, B.O.; OLIVEIRA, E.R.; QUEIROZ, F. Bioactive compounds and chemical composition of Brazilian Cerrado fruits' wastes: pequi almonds, murici, and sweet passionfruit seeds. Food Science and Technology, Campinas, v.38, n.1, p.203-214, 2018.

DAMIANI, C.; ALMEIDA, T.L.; COSTA, N.V.; MEDEIROS, N.X.; SILVA, A.G.M.; SILVA, F.A.; LAGE, M.E.; BECKER, F.S. Perfil de ácidos graxos e fatores antinutricionais de amêndoas de pequi crua e torrada. Pesquisa Agropecuária Tropical, Goiás, v.43, n.1, p.7178, 2013.

HARTMANN, L.; LAGO, R.C.A. Rapid preparation of fatty acid methyl esters from lipids. Laboratory Practices, London, v.22, p.475-477, 1973.

INSTITUTO ADOLFO LUTZ. Normas analíticas do Instituto Adolfo Lutz: métodos físico-químicos para análise de alimentos. São Paulo, 2008. 1020 p.

LIMA, A.L.; SILVA, A.M.O.; TRINDADE, R.A.; TORRES, R.P.; MANCINI-FILHO, J. Composição química e compostos bioativos presentes na polpa e na amêndoa do pequi (Caryocar brasiliense, Camb.). Revista Brasileira de Fruticultura, Jaboticabal, v.29, n.3, p.695698, 2007.

LIMA, J.R.; PINTO, G.A.S.; MAGALHÃES, H.C.R .Óleo da amêndoa de castanha-de-caju: métodos de extração. Fortaleza: Embrapa Agroindústria Tropical, 2018. (Boletim de Pesquisa e Desenvolvimento, 165).
LORENZI, H. Árvores brasileiras: manual de identificação e cultivo de plantas arbóreas nativas do Brasil. 4.ed. Nova Odessa: Plantarum, 1992. v.1, 368p.

MOODLEY, R., KINDNESS, A.; JONNALAGADDA, S.B. Elemental composition and chemical characteristics of five edible nuts (almond, Brazil, pecan, macadamia and walnut) consumed in Southern Africa. Journal of Environmental Science and Health, London, v.42, n.5, p.585-591, 2007.

NAVARRO, S.L.B.; RODRIGUES, C.E.C. Macadamia oil extraction methods and uses for the defatted meal byproduct. Trends in Food Science \& Technology, Amsterdan, v.54, p.148-154, 2016.

OLIVEIRA, M.E.B; GUERRA, N.B.; MAIA, A.H.N; ALVES, R.E.; MATOS, N.M.S.; SAMPAIO, F.G.M.; LOPES, M.M.T. Características químicas e físicoquímicas de pequis da Chapada do Araripe, Ceará. Revista Brasileira de Fruticultura, Jaboticabal, v.32, n.1, p.114125, 2010a.

OLIVEIRA, M.L.M.; PINHEIRO, D.C.S.N.; TOMÉ, A.R.; MOTA, E.F.; VERDE, I.A.L.; PINHEIRO, F.G.M.; CAMPELLO, C.C.; MORAIS, S.M. In vivo topical antiinflammatory and wound healing activities of the fixed oil of Caryocar coriaceum Wittm. Seeds. Journal of Ethnopharmacology, v.129, p.214-219, 2010b.

PROTIMIZA. Protimiza experimental design. 2020. Disponível em: experimental-design.protimiza.com.br. Acesso em: 12 maio 2010.

RAMOS, K.M.C.; SOUZA, V.A.B. Características físicas e químico-nutricionais de frutos de pequizeiro (Caryocar coriaceum wittm.) em populações naturais da região meio-norte do Brasil. Revista Brasileira de Fruticultura, Jaboticabal, v.33, n.2, p.500-508, 2011.

SILVA, M.A.P.; MEDEIROS FILHO, S. Morfologia de fruto, semente e plântula de pequi (Caryocar coriaceum Wittm.). Revista Ciência Agronômica, Fortaleza, v.37, n.3, p.320-325, 2006.

TORRES, L.R.O.; SANTANA, F.C.; TORRES-LEAL, F.L.; MELO, I.L.P.; YOSHIME, L.T.; MATOS-NETO, E.M.; SEELAENDER, M.C.L.; ARAÚJO, C.M.M.; COGLIATI, B.; MANCINI-FILHO; J. Pequi (Caryocar brasiliense Camb.) almond oil attenuates carbono tetrachloride-induced acute hepatic injury in rats: antioxidant and anti-inflammatory effects. Food and Chemical Toxicology, Oxford, v.97, p.205-216, 2016. 